\title{
ВMJ Global Health Decriminalisation of gender-based violence is a global health problem
}

\author{
Jenevieve Mannell, Sarah Hawkes
}

To cite: Mannell J, Hawkes S Decriminalisation of genderbased violence is a global health problem. BMJ Glob Health 2017;2:e000438. doi:10.1136/ bmjgh-2017-000438

Handling editor Seye Abimbola

Received 7 June 2017 Revised 24 July 2017 Accepted 25 July 2017
CrossMark

Institute for Global Health, University College London, London, UK

Correspondence to Dr Jenevieve Mannell; j.mannell@ucl.ac.uk

\section{INTRODUCTION}

In July 2017 the member states of the United Nations (UN) came together to review progress towards six of the Sustainable Development Goals (SDGs), including goal 3 (health) and goal 5 (gender equality). The targets within goal 5 are broad and ambitious, incorporating a commitment to 'end all forms of discrimination against all women and girls everywhere' and also to 'eliminate all forms of violence against all women and girls in the public and private spheres'. Among other indicators, countries are being asked to report on the presence or absence of legal frameworks to enforce and monitor equality and non-discrimination on the basis of sex, as well as the proportion of women and girls who report suffering from violence. However, contrary to the ideals enshrined within Agenda 2030 for Sustainable Development, at the level of some individual states, there has been a rolling back of legislation protecting against violence and discrimination. This presents a global health problem because of the significant impacts the removal of this protective legislation has on the health of women, children and those with marginalised gender or sexual identities.

\section{RECENT ROLL-BACK OF LEGISLATION AGAINST GENDER-BASED VIOLENCE}

In February 2017 the President of Russia, Vladimir Putin, signed into law legislation that decriminalised a first offence of violence committed against family members, including children and spouses. This amendment, supported by 385 of 387 Russian Members of Parliament, effectively reduced the penalty for first offences of violence that do not cause lasting bodily harm from twoyears in prison to a fine of up to 30000 roubles (less than US\$500). Intimate partner and domestic violence in Russia is described as 'seriously underreported, under-recorded and largely ignored by the authorities'. ${ }^{2}$ The UN

\section{Summary box}

In some countries we are seeing a recent roll-back of legislation protecting survivors of gender-based violence.

- This is a global health problem because of the implications for the health of women, children and those with marginalised gender or sexual identities.

- A growing body of evidence points to the serious consequences of gender-based violence for both physical and mental health outcomes, which is not being considered in these legislative changes.

- The United Nation's Sustainable Development Goals provide a key moment for ensuring that states uphold global commitments to gender equality and non-discrimination on the basis of gender or sexual identities.

Committee on the Elimination of Discrimination Against Women in its 2010 review of the Russian Federation noted 'serious concern' over the increase in domestic violence in the country and the 'legitimizing of a general opinion that domestic violence is a private issue'.

Other countries, such as Afghanistan, have seen strong political movements against any protection for women experiencing violence. Afghanistan has a small number of internationally funded safe houses that provide temporary shelter and legal aid for women. These safe houses are highly politicised for protecting women who, in leaving their violent husbands, have committed what many Afghans consider to be 'moral crimes'. In 2012, the then Justice Minister, Habibullah Ghaleb, referred to the safe houses as 'centres of prostitution' in an address to parliament. ${ }^{4}$ Similarly, in Bahrain, a proposed bill to consider violence against women in national legislation has been blocked since 2007 because of disagreements over its compatibility with Sharia law. ${ }^{5}$ This has left the country with no legal reference to domestic or intimate partner violence; this is also the case in Iran, Kuwait and Iraq (where 
a husband actually has the legal right to punish his wife with physical abuse).

Other countries have seen positive changes in legislation protecting women against domestic violence with new laws in Rwanda in 2009, Uganda in 2010 and Saudi Arabia in 2013. While this shows some progress, violence against women in domestic household settings is only one form of violence on a wide spectrum of gender-related violences, and these legal changes therefore only scratch the surface of a deeply rooted issue. Violence based on gender or sexuality shares common roots in power structures that seek to enforce ideals of 'appropriate' masculinity or femininity. While the SDG commitments require countries to report only on violence against women and girls, evidence and experience show that victims of gender-based violence (GBV) can be male or female, transgender, homosexual or heterosexual, and that the violence itself is enacted by family members, communities or state agents. ${ }^{6}$

Adopting this broader understanding of GBV highlights the severe implications gender legislation can have for human rights and health. For instance, same-sex relationships are criminalised in 74 countries worldwide, and punishable by death in parts of Nigeria, Sudan, Iran, Saudi Arabia, Yemen, Qatar, Somalia and Mauritania. Efforts to increase the severity of punishments for same-sex behaviour, such as the Anti-Homosexuality Act in Uganda signed into law in 2014 (which aimed to replace life imprisonment with the death penalty), have political momentum in a number of countries including Nigeria, Kenya, Democratic Republic of Congo, Ghana and Zimbabwe. ${ }^{7}$ While Uganda's law was eventually overturned for procedural inconsistencies, the public debate surrounding the Act has contributed to the further entrenchment of inequality and discrimination by condoning community acts of violence. ${ }^{8}$ Again, there are examples of changing legislation in support of lesbian, gay, bisexual and transgender (LGBT) rights; Taiwan, for example, is now the first country in Asia to legalise same-sex marriage. However, huge legal barriers remain elsewhere in the region, including in Singapore, South Korea, Afghanistan and India. ${ }^{9}$ Progress is therefore patchy, and protective measures for GBV can easily change with a changing political climate. In India, for example, legislation outlawing homosexual sex dating back to 1860 was overturned by the Delhi High Court in 2009 as unconstitutional. However, in 2013, the Supreme Court rejected the 2009 decision, in effect returning to a punishment of 10 years in prison for any same-sex relations. $^{10}$

\section{EMERGING EVIDENCE ON THE HEALTH CONSEQUENCES OF GBV}

Emerging evidence by violence researchers suggests that these trends in reducing legal protections against GBV for women and LGBT+ populations are not only a clear violation of human rights, but will have disastrous consequences for human health worldwide. In the past 5 years, a substantial body of evidence has accumulated on the severe implications that GBV has for health outcomes. In 2013, the WHO undertook an unprecedented global study of GBV prevalence and its health effects, producing devastating estimates that one in three women will experience physical or sexual violence from an intimate partner in their lifetime. ${ }^{11}$ Moreover, the study concluded that the consequences of such violence are widespread for example, women who experience physical and/or sexual violence are 1.5 times more likely to acquire HIV. Individuals from stigmatised groups, including LGBT+, sex workers and migrants, are particularly vulnerable because of how violence against these individuals may not be recognised by personal support networks or health providers. ${ }^{12}$

The significant mental health consequences of physical and sexual violence have been well established by the literature, including higher rates of depression, ${ }^{13}$ post-traumatic stress disorder, ${ }^{14}$ anxiety, ${ }^{15}$ alcohol and drug abuse, ${ }^{16}$ and suicidal ideation. ${ }^{13}$ However, an emerging body of evidence points to the health consequences of more insidious forms of violence, such as emotional violence and controlling behaviours. While often assumed to be 'lesser' forms of violence requiring less severe legal measures by the state, ${ }^{17}$ recent studies have shown that a low level of equity within a relationship may be as important a risk factor for HIV acquisition as physical violence. ${ }^{18}$ In a similar vein, symptoms of postnatal depression may be more strongly associated with psychological violence than with physical or sexual violence. ${ }^{19}$ The importance of emotional forms of violence can no longer be ignored if addressing health outcomes is the goal.

\section{THE IMPORTANCE OF LEGISLATION}

Legislation that decriminalises GBV severely undermines efforts to address the health consequences of physical, sexual and emotional forms of violence. First, women who live in countries with domestic violence legislation are $7 \%$ less likely to experience violence than those who do not. ${ }^{20}$ Second, rates of reporting are likely to fall when victims know that perpetrators will go unpunished, or fear that the law is more concerned with punishing the transgression of norms of gender or sexuality than in providing a safe violence-free environment for all. This results in the silencing of GBV experiences and hiding health consequences from police, health service, friends and family members. Legislation also has significant implications for efforts to address the social norms that condone violence and see it as an acceptable means of ensuring conformity in relation to gender and sexuality. The decriminalisation of GBV sends a broader message to society that violence is acceptable within particular constraints, such as lasting bodily harm or repeat beatings, and further serves to overlook the lasting damage due to emotional or psychological forms of violence, as well as the significant mental health outcomes that arise from all forms of violence. 


\section{CONCLUSION}

Elimination of violence, including the cultural acceptance of violence, is fundamental to achieving societies where all people have the capacity to live dignified lives free from fear, discrimination and associated poor health outcomes, and all UN member states have signed a commitment to eliminate such violence against women and girls. The law can serve to underpin efforts at elimination, but legislation against violence on the grounds of gender or sexuality is a recent phenomenon and is still woefully incomplete in many societies. For example, although the UK agreed to the Council of Europe Convention on preventing and combating violence against women and domestic violence (the so-called Istanbul Convention) in 2012, it took until 2017 for the Parliament to agree to ratify the Convention. After decades of national and international struggles to enshrine antiviolence commitments into national laws and global commitments, now is not the time to renege on our obligations to ensure human rights are for all and not just for a select few on the basis of the power of their gender or sexual identities.

Contributors JM and SH jointly conceptualised and wrote the paper.

Competing interests None declared.

Provenance and peer review Not commissioned; externally peer reviewed.

Data sharing statement Not applicable

Open Access This is an Open Access article distributed in accordance with the Creative Commons Attribution Non Commercial (CC BY-NC 4.0) license, which permits others to distribute, remix, adapt, build upon this work non-commercially, and license their derivative works on different terms, provided the original work is properly cited and the use is non-commercial. See: http://creativecommons.org/ licenses/by-nc/4.0/

(C) Article author(s) (or their employer(s) unless otherwise stated in the text of the article) 2017. All rights reserved. No commercial use is permitted unless otherwise expressly granted.

\section{REFERENCES}

1. UN Economics and Social Council. Sustainable Development Goal 5: Achieve gender equality and empower all women and girls, Sustainable Development Knowledge Platform, 2017. https:// sustainabledevelopment.un.org/sdg5

2. UN Economic and Social Council, Commission on Human Rights. Integration of the Human Rights of Women and a Gender Perspective: Violence Against Women. Report of the Special Rapporteur on violence against women, its causes and consequences. Mission to the Russian Federation. 62nd Session, 2006. E/CN.4/2006/61/Add.2.

3. UN Committee on the Elimination of Discrimination Against Women (CEDAW). Concluding Observations of the Committee on the Elimination of Discrimination Against Women: Russian Federation;
2010, Report No.: CEDAW/C/USR/CO/7. http://tbinternet.ohchr. org/_layouts/treatybodyexternal/Download.aspx?symbolno= CEDAW/C/USR/CO/7\&Lang=en

4. Rasa S. 'Afghanistan: Women Seek Refuge in Safe Houses' Institute for War and Peace Reporting. 20 Apl 2017 https://iwpr.net/globalvoices/afghanistan-women-seek-refuge-safe-houses (accessed 10 Jul 2017).

5. Seikaly M, Roodsaz R, van Egten C. The Situation of Women in the Gulf States. European Parliament, Directorate General for Internal Policies, Women's Rights and Gender Equality, Report PE 509 985, 2014. http://www.europarl.europa.eu/RegData/etudes/STUD/2014/ 509985/IPOL_STU(2014)509985_EN.pdf

6. World Health Organisation. Sexual health, human rights and the law. Geneva: WHO, 2015. http://www.who.int/reproductivehealth/ publications/sexual_health/sexual-health-human-rights-law/en/

7. Beyrer C. Pushback: the current wave of anti-homosexuality laws and impacts on health. PLoS Med 2014;11:e1001658.

8. Semugoma P, Beyrer C, Baral S. Assessing the effects of antihomosexuality legislation in Uganda on HIV prevention, treatment, and care services. Sahara J 2012;9:173-6.

9. Let's hear it for Taiwan. The Economist. New york. (accessed 24 Jun 2017).

10. Shyamantha A. 'India's Supreme Court turns the clock back with gay sex ban': Reuters, 2013. 11 Dec 2013. (accessed 10 Jul 2017).

11. World Health Organisation, London School of Hygiene and Tropical Medicine, South African Medical Research Council. Global and regional estimates of violence against women: Prevalence and health effects of intimate partner violence and non-partner sexual violence. Geneva, Switzerland: World Health Organisation, 2013. http://www. who.int/reproductivehealth/publications/violence/9789241564625/ en/

12. Schumacher EC, Bishop CN, Prejudice CNM. discrimination and mental health status within the lesbian, gay and bisexual community. Psychology of Prejudice: New Research, 2014:121-34. https://w ww.scopus.com/inward/record.uri?eid=2-s2.0-84954315844\&partn erlD=40\&md5=f423a4dd595b5e3c6c950c52da41be72

13. Estefan LF, Coulter ML, VandeWeerd C. Depression in Women Who Have Left Violent Relationships: The Unique Impact of Frequent Emotional Abuse. Violence Against Women 2016;22:1397-413.

14. Kastello JC, Jacobsen KH, Gaffney KF, et al. Posttraumatic stress disorder among low-income women exposed to perinatal intimate partner violence : Posttraumatic stress disorder among women exposed to partner violence. Arch Womens Ment Health 2016;19:521-8

15. Kader Maideen SF, Mohd Sidik S, Rampal L, et al. Prevalence, associated factors and predictors of anxiety: a community survey in Selangor, Malaysia. BMC Psychiatry 2015;15:262.

16. Jaquier V, Flanagan JC, Sullivan TP. Anxiety and posttraumatic stress symptom pathways to substance use problems among community women experiencing intimate partner violence. Anxiety Stress Coping 2015;28:445-55.

17. Mannell J, Dadswell A. Preventing Intimate Partner Violence: Towards a Framework for Supporting Effective Community Mobilisation. J Community Appl Soc Psychol 2017 (Epub ahead of print 2017).

18. Jewkes R, Dunkle K, Jama-Shai N, et al. Impact of exposure to intimate partner violence on CD4+ and CD8+ T cell decay in HIV infected women: longitudinal study. PLoS One 2015;10:e0122001.

19. Ludermir AB, Lewis $G$, Valongueiro $S A$, et al. Violence against women by their intimate partner during pregnancy and postnatal depression: a prospective cohort study. Lancet 2010;376:903-10.

20. Klugman J, Hanmer L, Twigg S, et al. Voice and Agency: Empowering Women and Girls for Shared Prosperity. Washington, DC: World Bank Group, 2014. 